\title{
Treatment of Chromium Waste in a Constructed Wetland System: Insights from Microcosm Experiments
}

\author{
Devi N. Choesin, Priza M. Triawan, Ella Laelasari, and Wisya A. Prayudi
}

\begin{abstract}
Use of constructed wetland systems (CWS) is a relatively inexpensive, effective, and environmentally-friendly approach in treating various types of waste, including waste containing heavy metals such as chromium $(\mathrm{Cr})$. These systems function by simulating natural wetland processes which rely on the respective roles of wetland hydrology, substrate, and biota, particularly plants and microbes. This paper presents main results from three laboratory (microcosm) experiments to study the effects of plant variation, bacterial isolate addition, and substrate variation on system effectiveness in removing $\mathrm{Cr}$ from simulated wastewater. Plants were varied by species and life form (emergent vs. floating). Bacterial consortium was isolated from a site known to contain high $\mathrm{Cr}$ concentration. Overall results demonstrate that all CWS designs were effective in reducing $\mathrm{Cr}$ concentration in water when compared to the control without substrate, plants or bacterial addition. The added bacterial consortium significantly improved system effectiveness. In the short term, presence of plants or variation of their lifeform did not significantly affect CWS effectiveness, while varying substrate with the addition of coconut shell charcoal or activated charcoal tend not to produce significant effects when compared to standard soil substrate. These findings provide insights to be considered when designing optimum conditions for constructed wetland systems to treat wastewater containing $\mathrm{Cr}$ as heavy metal contaminant.
\end{abstract}

Keywords - chromium, constructed wetland, waste treatment.

\section{INTRODUCTION}

Environmental pollution due to untreated wastewater containing heavy metals is an important issue that must be addressed in many countries. Among heavy metal contaminants, chromium $(\mathrm{Cr})$ is known to be present in high concentrations, as it is used in various industrial operations, mostly in steel production, chrome plating, and leather tanning [1]. Various physicochemical methods have been developed to process heavy metal contaminants such as $\mathrm{Cr}$, e.g., ion exchange, activated carbon and chemical precipitation [2]; however, these methods tend to produce undesirable side effects. In the last few decades, the use of constructed wetland systems (CWS) has become a popular alternative because it is relatively inexpensive, effective, and more environmentally-friendly.

The removal mechanism of heavy metals in CWS is a complex combination of physicochemical and biological processes [3]; and relies on the respective roles of wetland

Manuscript received January 13, 2016. This work was supported in part by a grant from the Institute of Research and Community Services (LPPM) of Institut Teknologi Bandung (ITB) through its 2015 Research Grant program.

Authors are affiliated with the Biology program, School of Life Sciences and Technolgy, Institut Teknologi Bandung, Jalan Ganesha 10, Bandung 40132, Indonesia hydrology, substrate, and biota, particularly plants and microbes. Continuing research is required in order to optimize the role of these three components in enhancing the effectiveness of CWS in treating wastewater. In addition, other technical aspects related to the design of the system, e.g., direction of water flow and retention time must also be considered. Indeed the most important parameter in achieving high $\mathrm{Cr}$ removal efficiencies is the selection of optimal CWS type [2].

In this paper, we summarize main results from three different laboratory (microcosm) experiments in which CWS were varied to study the effects of plant variation, bacterial isolate addition, and substrate variation on system effectiveness in removing $\mathrm{Cr}$ from simulated wastewater. The specific objectives of the three experiments were respectively to study the effects of: (1) adding Scirpus grossus and Pistia stratiotes as plant components, and bacterial isolate in a sequential CWS with water recirculation; (2) varying plant life form (i.e., emergent vs. floating) and adding bacterial isolate in a non-sequential/single compartment system with water recirculation; and (3) adding coconut shell charcoal and activated charcoal to soil substrate in a batch system containing $P$. stratiotes.

\section{Methodology}

\section{A. Experiment 1: Use of a sequential CWS with bacterial isolate addition}

In this experiment, three CWS were compared, i.e., a system planted with Scirpus grossus and Pistia stratiotes with the addition of bacteria isolated from a site known to contain high concentration of $\mathrm{Cr}$ due to its proximity to industrial pollution sources (this system coded S1); a system containing both plant species without the addition of bacterial isolates (S2); and a control system without added plants or bacteria (S3) [4]. Each system was built as a sequence of two glass aquariums, each measuring $50 \mathrm{~cm} \times 30 \mathrm{~cm} \times 30 \mathrm{~cm}$. Substrate in the form of soil, sand and gravel was placed in the first aquarium where $S$. grossus was planted. Treatments were replicated three times. The flow of water was set as free water surface with recirculation. Simulated $\mathrm{Cr}$ waste was added in the form of $\mathrm{K}_{2} \mathrm{Cr}_{2} \mathrm{O}_{7}$ with a concentration of $4.5 \mathrm{mg} / \mathrm{L} \mathrm{Cr}$. Six genera of bacteria in the isolates were later identified as Comamonas, Methylobacterium, Enterobacter, Alcaligenes, Shigella, and Xanthobacter. Effectiveness of systems was measured based on the concentration of $\mathrm{Cr}$ remaining in water after 14 days. Plant fresh weight, $\mathrm{Cr}$ content in plants, as well as $\mathrm{Cr}$ content in substrate were also measured. 


\section{B. Experiment 2: Effects of bacterial isolate addition and plant life form variation}

Five different CWS were tested, i.e., system 1 contained substrate only (coded Su); system 2 contained substrate and the plant Pistia stratiotes (Su+Ps); system 3 contained substrate and the plant Scirpus grossus (Su+Sg); system 4 contained substrate, $P$. stratiotes and bacteria $(\mathrm{Su}+\mathrm{Ps}+\mathrm{B})$; and system 5 contained substrate, S. grossus and bacteria $(\mathrm{Su}+\mathrm{Sg}+\mathrm{B})$ [5]. Each system consisted of a single (i.e., non-sequential) aquarium measuring $50 \mathrm{~cm} \times 30 \mathrm{~cm} \times 30 \mathrm{~cm} . P$. stratiotes is a free floating plant, while $S$. grossus is an emergent plant rooted in substrate. The experiment was conducted using $4.5 \mathrm{mg} / \mathrm{L}$ simulated $\mathrm{Cr}$ waste, and was run for 14 days. Bacteria added was from the same source as in Experiment 1.

\section{Experiment 3: Effect of substrate variation using coconut shell charcoal/activated charcoal}

Five different CWS treated with simulated $\mathrm{Cr}$ wastewater were compared: system 1 as a control system contained only simulated wastewater without Pistia stratiotes or substrate (coded W); system 2 contained $P$. stratiotes $(\mathrm{W}+\mathrm{Ps})$; system 3 contained P. stratiotes and $100 \%$ soil substrate $(\mathrm{W}+\mathrm{Ps}+\mathrm{So})$; System 4 contained $P$. stratiotes and $75 \%$ soil substrate $+25 \%$ coconut shell charcoal $(\mathrm{W}+\mathrm{Ps}+\mathrm{Ch})$; and system 5 contained $P$. stratiotes and $75 \%$ soil substrate $+25 \%$ coconut shell activated charcoal as substrate $(\mathrm{W}+\mathrm{Ps}+\mathrm{Ach})$ [6]. Systems were made from glass aquariums measuring $60 \mathrm{~cm} \times 30 \mathrm{~cm} \times 35 \mathrm{~cm}$. Each system was exposed to simulated waste from $\mathrm{K}_{2} \mathrm{Cr}_{2} \mathrm{O}_{7}$ with total $\mathrm{Cr}$ concentration of $15 \mathrm{mg} / \mathrm{L}$ for 15 days.

In all three experiments, effectiveness of systems was measured based on the concentration of $\mathrm{Cr}$ remaining in water which indicates the percentage of $\mathrm{Cr}$ removal. Concentration of $\mathrm{Cr}$ in samples was measured by using atomic absorption spectrophotometry (AAS).

\section{RESULTS AND DISCUSSION}

\section{A. Experiment 1: Use of a sequential CWS with bacterial isolate addition}

The decrease of $\mathrm{Cr}$ in water occurred most rapidly in $\mathrm{S} 1$ (containing Scirpus grossus, Pistia stratiotes and bacteria) after seven days, with $\mathrm{Cr}$ removal of $82.21 \pm 10.9 \%$ (Figure 1). Measurements of $\mathrm{Cr}$ concentrations were significantly different among systems $(\mathrm{p}<0.05)$. After seven days, $\mathrm{Cr}$ concentration in S1 had already met standard concentration (maximum allowable concentration) for water, i.e., $0.5 \mathrm{mg} / \mathrm{L}$. The lowest percentage of Cr removal efficiency occurred in S3 (control), i.e., $52.83 \pm 28.73 \%$.

At the end of the experiment, $\mathrm{Cr}$ concentrations in $S$. grossus ranged from 1.67 to $3.68 \mathrm{mg} / \mathrm{kg}$ dry weight in roots and 0.1 to $0.29 \mathrm{mg} / \mathrm{kg}$ dry weight in shoots; while concentrations in $P$. stratiotes ranged from 3.75 to $5.62 \mathrm{mg} / \mathrm{kg}$ dry weight in roots and 0.19 to $0.45 \mathrm{mg} / \mathrm{kg}$ dry weight in shoots. Final concentrations of $\mathrm{Cr}$ in substrate were not significantly different among the three systems. Plant fresh weight at the beginning and end of exposure to $\mathrm{Cr}$ waste were not significantly different. Overall results of this experiment revealed that the system containing plants and added with bacteria was more effective than the other two systems.

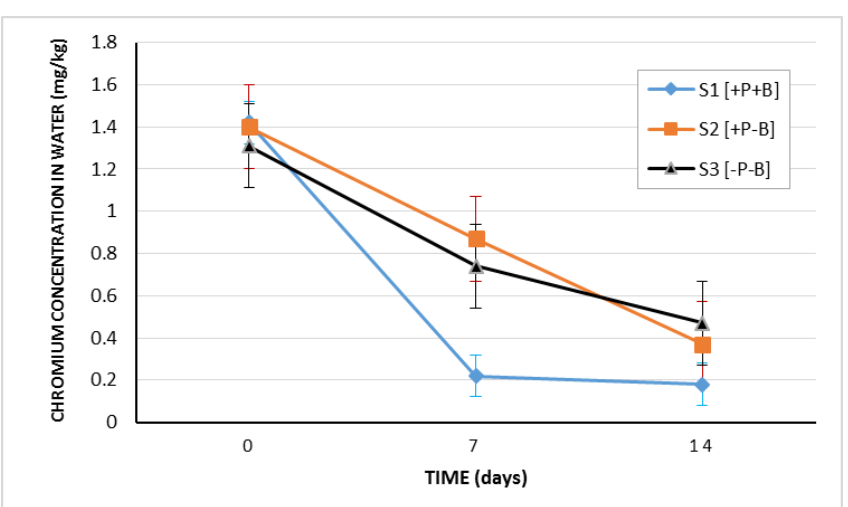

Fig. 1. Reduction in $\mathrm{Cr}$ concentration in water after 14 days of treatment in a sequential CWS with recirculation $(\mathrm{S}=$ system; $\mathrm{P}=$ plants; $\mathrm{B}=$ bacteria $)$.

\section{B. Experiment 2: Effects of bacterial isolate addition and plant life form variation}

Measurement results indicate that $\mathrm{Cr}$ concentrations decreased the most in system 5 containing substrate, Scirpus grossus and bacteria $(\mathrm{Su}+\mathrm{Sg}+\mathrm{B})$ (i.e., $86.93 \pm 1.94 \%$ ) and least in system 1 containing only substrate $(62.59 \pm 1.43 \%)$ (Figure $2)$. Although there were no significant differences among systems 2 to 5 , final $\mathrm{Cr}$ concentration in these four systems were significantly different from system 1 as control $(\mathrm{p}<0.05)$.

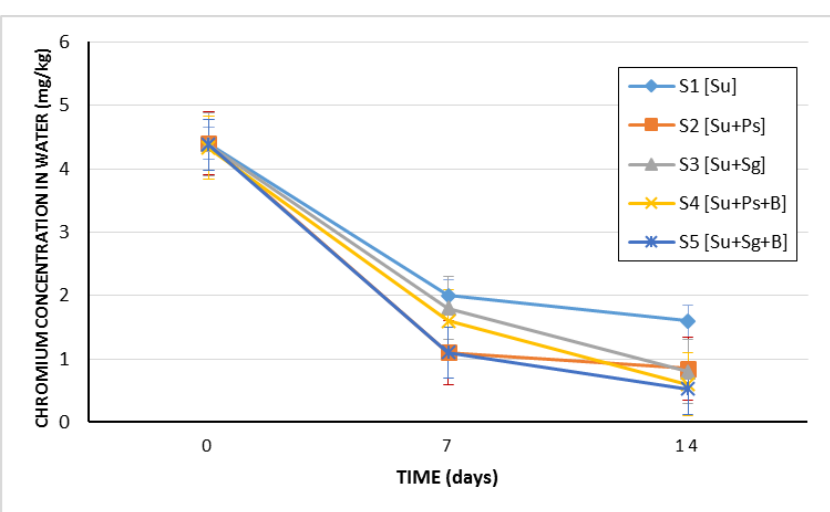

Fig. 2. Reduction in $\mathrm{Cr}$ concentration in water after 14 days of treatment in a non-sequential CWS with recirculation, varied by plant composition and bacterial isolate addition $(\mathrm{S}=$ system; $\mathrm{Su}=$ substrate; $\mathrm{Ps}=$ Pistia stratiotes; $\mathrm{Sg}=$ Scirpus grossus; $\mathrm{B}=$ bacteria).

Highest $\mathrm{Cr}$ accumulation was found in $S$. grossus, both in root and shoot. Chromium accumulation in $S$. grossus measured $161.59 \mu \mathrm{g} / \mathrm{g}$ dry weight in system $3(\mathrm{~S}+\mathrm{Sg})$ and $198.09 \mu \mathrm{g} / \mathrm{g} \mathrm{dw}$ in system $5(\mathrm{~S}+\mathrm{Sg}+\mathrm{B})$; these measurements were higher than in P. stratiotes, i.e., $62.01 \mu \mathrm{g} / \mathrm{g} \mathrm{dw}$ in system $2(\mathrm{~S}+\mathrm{Ps})$ and 83.51 $\mu \mathrm{g} / \mathrm{g} \mathrm{dw}$ in system $4(\mathrm{~S}+\mathrm{Ps}+\mathrm{B})$. Chromium accumulation in substrate occurred the most in system 1 containing substrate only $(100.93 \pm 7.58 \mu \mathrm{g} / \mathrm{g} \mathrm{dw})$ and least in system 5 containing substrate, $S$. grossus and bacteria $(22.73 \pm 7 \mu \mathrm{g} / \mathrm{g} \mathrm{dw})$.

Results of this experiment suggest that adding bacteria increased system effectiveness in reducing $\mathrm{Cr}$ concentration in water, but did not affect $\mathrm{Cr}$ accumulation in plants and substrate. Variation in plant species and life form produced differences in $\mathrm{Cr}$ accumulation levels; however neither, plant species significantly affected the reduction of $\mathrm{Cr}$ concentrations in water. 


\section{Experiment 3: Effect of substrate variation using coconut shell charcoal/activated charcoal}

All systems were effective in reducing total $\mathrm{Cr}$ concentration in water (Figure 3). System 4 (with charcoal added to substrate) reduced the most total $\mathrm{Cr}$, i.e., 97.8\%. However, overall reduction in total $\mathrm{Cr}$ concentration in water was not significantly different among systems ( $p>0.05$ ), suggesting that the addition of activated charcoal and charcoal did not affect the system in lowering total $\mathrm{Cr}$ concentration in water. Soil substrate accumulated the highest total $\mathrm{Cr}$, with total $\mathrm{Cr}$ accumulation of 12.7\%; however, the effectiveness of soil, charcoal, and activated charcoal were not significantly different ( $p>0.05$ ).

Based on the results, it could be concluded that the addition of coconut shell charcoal and activated charcoal to the soil substrate did not affect CWS effectiveness in reducing total $\mathrm{Cr}$ concentrations in water within a period of 15 days; however, there were significant differences in $\mathrm{Cr}$ concentration reduction measured at 3-day periods. Furthermore, the addition of activated charcoal and charcoal did not affect the accumulation of $\mathrm{Cr}$ in $P$. stratiotes or in substrate. Although substrate variation had no effect on the system's effectiveness in decreasing total $\mathrm{Cr}$ concentration, final $\mathrm{Cr}$ concentration in the systems met the standard concentration level; final measurements were below the maximum allowable concentration for water, i.e., $0.5 \mathrm{mg} / \mathrm{L}$.

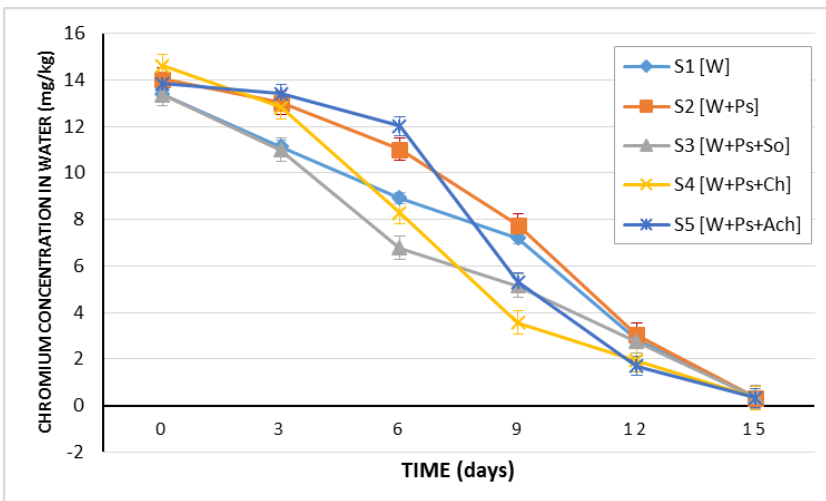

Fig. 3. Reduction in $\mathrm{Cr}$ concentration in water after 15 days of treatment in CWS varied by substrate composition ( $\mathrm{S}=$ system; $\mathrm{W}=$ water; $\mathrm{Ps}=$ Pistia stratiotes; $\mathrm{So}=$ soil; $\mathrm{Ch}=$ charcoal; $\mathrm{Ach}=$ activated charcoal).

\section{CONCLUSION}

The findings presented above have provided a sampling of results from three microcosm experiments designed to test the effectiveness of CWS and optimize their functioning.
Experimental results suggest that the appropriate bacterial isolate addition could significantly enhance system effectiveness in reducing $\mathrm{Cr}$ concentrations in water. This identification was conducted as a preliminary study to further reveal the potential of bacteria for $\mathrm{Cr}$ removal or assist plants in absorbing Cr.

Variation in plant species or life form (i.e., emergent vs. floating) tend not to affect the performance of CWS in the short term. Finally, varying CWS substrate with the addition of coconut shell charcoal or activated charcoal did not produce significant effects when compared to standard soil substrate. Findings from the experiments described provide insights to be considered when designing optimum conditions for CWS to treat wastewater containing $\mathrm{Cr}$ as heavy metal contaminant.

\section{REFERENCES}

[1] H. S. Altundogan, " $\mathrm{Cr}(\mathrm{VI})$ removal from aqueous solution by iron (III) hydroxide-loaded sugar beet pulp," Process Biochem. vol. 40, pp. 1443-1452, 2005. http://dx.doi.org/10.1016/j.procbio.2004.06.027

[2] M-Y Sultana, C. S. Akratos, S. Pavlou, and D. V. Vayenas, "Chromium removal in constructed wetlands: a review," International Biodeterioration \& Biodegradation, no. 96, pp. 181-190, 2004.

[3] R. H. Kadlec, and S. D. Wallace. "Treatment Wetlands," third edition, CRC Press, Boca Raton, FL, 2009.

[4] P. M. Triawan, "Use of a sequential constructed wetland system with bacterial isolate addition in treating simulated chromium (Cr) waste", B.Sc. thesis (in Indonesian), Biology Program, Institut Teknologi Bandung, Indonesia, 2011.

[5] E. Laelasari. "Effects of bacteria addition and plant life form variation on the effectiveness of a constructed wetland system in treating chromium waste", B.Sc. thesis (in Indonesian), Biology Program, Institut Teknologi Bandung, Indonesia, 2011.

[6] W.A. Prayudi and D. N. Choesin, "Effect of substrate variation on constructed wetland system effectiveness in reducing total chromium concentration in water", Proceedings of International Conference on Food, Ecological and Life Sciences (FELS-2015), June 15-16, 2015, Bangkok (Thailand). Pp.21-27. http://dx.doi.org/10.17758/ER61502. 